\title{
GAMBARAN PENDERITA DIARE PADA BALITA DI UPTD PUSKESMAS II DINAS KESEHATAN KECAMATAN DENPASAR BARAT PERIODE JUNI-NOVEMBER TAHUN 2019
}

\author{
M. Fakhrurrozi, I Made Subrata \\ Program Studi Sarjana Kesehatan Masyarakat Fakultas Kedokteran Universitas Udayana \\ Jalan P.B. Sudirman, Dangin Puri Klod, Kecamatan Denpasar Barat, Bali 80234
}

\begin{abstract}
ABSTRAK
Di Kota Denpasar, pada tahun 2019 ditemukan dan dilayani sebanyak 4923 balita penderita diare atau 30,8\% dari jumlah perkiraan kasus. Penelitian ini bertujuan untuk mengetahui gambaran penderita diare pada balita di UPTD Puskesmas II Dinas Kesehatan Kecamatan Denpasar Barat Periode Juni-November tahun 2019. Penelitian ini merupakan penelitian kuantitatif, dengan rancangan penelitian deskriptif dan menggunakan desain penelitian cross sectional. Total sampel sebanyak 79 balita. Teknik pengambilan menggunakan total sampling. Data bersumber dari data sekunder UPTD Puskesmas II Dinas Kesehatan Kecamatan Denpasar Barat. Analisis data menggunakan analisis univariat. Hasil dan kesimpulan penelitian menunjukan di UPTD Puskesmas II Dinas Kesehatan Kecamatan Denpasar Barat Periode Juni-November Tahun 2019. Penderita diare terbanyak dialami balita berjenis kelamin laki-laki sebanyak $60,76 \%$. Penderita diare pada balita terbanyak terjadi pada kategori umur 12 - 36 bulan sebanyak 54,43\%. Penderita diare pada balita terbanyak dari Desa Padangsambian Kelod sebanyak $32,91 \%$. Mayoritas penderita diare tanpa dehidrasi sebanyak 75,95\% balita, terdapat juga 24,05 penderita dengan dehidrasi ringan/sedang. Terdapat $26,58 \%$ balita penderita diare mendapatkan cairan ringer laktat. Terdapat $12,66 \%$ balita penderita diare mendapatkan antibiotik. Disarankan Puskesmas melalui posyandu lebih intensif melakukan program sosialisasi terkait tindakan pencegahan dan penanganan kepada orang tua yang memiliki balita, terutama balita laki-laki dan balita berusia $12-36$ bulan.
\end{abstract}

Kata kunci: Diare, Balita, Dehidrasi, Puskesmas II Denpasar Barat

\begin{abstract}
In Denpasar City, in 2019 it was found and served as many as 4923 toddlers with diarrhea or 30.8\% of the estimated number of cases. This study aims to find out the description of diarrhea sufferers in toddlers at the UPTD Puskesmas II, West Denpasar District Health Office for the period of June-November 2019. This research is a quantitative research, with a descriptive research design and using a cross sectional research design. The total sample is 79 toddlers. The sampling technique used was total sampling. Data sourced from secondary data from UPTD Puskesmas II, West Denpasar District Health Office. Data analysis used univariate analysis. The results and conclusions of the study show that at the UPTD Puskesmas II, West Denpasar District Health Office, for the JuneNovember period 2019. The most diarrhea sufferers are male toddlers, as much as $60.76 \%$. Diarrhea sufferers in toddlers mostly occurred in the age category $12-36$ months as much as $54.43 \%$. The most diarrhea sufferers in toddlers from Padangsambian Kelod Village were 32.91\%. The majority of patients with diarrhea without dehydration were $75.95 \%$ under five, there were also 24.05 patients with mild/moderate dehydration. There are $26.58 \%$ of toddlers with diarrhea get Ringer's lactate fluid. There are $12.66 \%$ of toddlers with diarrhea who get antibiotics. It is recommended that the Puskesmas through the posyandu carry out more intensive socialization programs related to prevention and treatment measures for parents who have toddlers, especially boys and toddlers aged 12-36 months.
\end{abstract}

Key words: Diarrhea, Toddlers, Dehydration, Public Health Center II, West Denpasar 


\section{PENDAHULUAN}

Penyakit diare adalah salah satu penyakit yang dapat terjadi pada semua kelompok usia, salah satu kelompok usia yang paling sering terserang diare yaitu balita. Diare didefinisikan sebagai kejadian buang air besar yang lembek atau cair sebanyak $3 \mathrm{kali}$ atau lebih per hari (atau lebih sering dari yang normal untuk individu) (WHO, 2017). Diare merupakan penyebab kedua kematian pada anak di bawah 5 tahun. Setiap tahunnya diare membunuh sekitar 525.000 anak balita. Secara global, setiap tahunnya ada hampir 1,7 miliar kasus penyakit diare anak-anak (WHO, 2017). Penyakit diare adalah salah satu penyakit yang dapat menyebabkan kematian pada anak-anak dibawah 5 tahun, terhitung sekitar $8 \%$ dari semua kematian anak-anak di bawah umur 5 tahun di seluruh dunia pada tahun 2017. Berarti, lebih dari 1.300 anak-anak meninggal setiap harinya. Sebagian besar kematian akibat penyakit diare terjadi pada anak-anak berusia kurang dari 5 tahun yang tinggal di Asia Selatan dan Sub-Sahara Afrika (UNICEF, 2020).

Di Indonesia, diare merupakan penyakit yang berpotensi Kejadian Luar Biasa (KLB) yang sering disertai dengan kematian. Berdasarkan data dan informasi profil kesehatan Indonesia tahun 2019, angka kesakitan diare pada balita yaitu 843 per 1000. Prevalensi diare berdasarkan diagnosis tenaga kesehatan sebesar 6,8\% dan berdasarkan diagnosis tenaga kesehatan dan gejala yang pernah dialami sebesar $8 \%$. Prevalensi penyakit diare pada balita berdasarkan diagnosis tenaga kesehatan yakni sebesar 11\% (Kemenkes RI, 2020).

Di Provinsi Bali, penyakit saluran pencernaan seperti diare masih cukup tinggi ditemukan dan masih menjadi masalah kesehatan. Pada tahun 2019 jumlah target kasus diare yang ditemukan pada balita sebesar 49.484 dan dilayani
18.640 kasus $(37,7 \%)$ dengan 1 kematian (Dinkes Provinsi Bali, 2020). Di Kota Denpasar, penyakit diare pada balita masih merupakan masalah kesehatan. Pada tahun 2019, di Kota Denpasar ditemukan dan ditangani 4923 balita penderita diare atau sebesar 30,8\% dari jumlah perkiraan kasus yang ada, kejadian ini mengalami peningkatan dibandingkan dengan kejadian di tahun 2018, dimana penderita diare yang ditemukan dan dilayani sebanyak 3523 balita. Case Fatality Rate (CFR) nya 0 (Dinkes Kota Denpasar, 2020). Di wilayah kerja UPTD Puskesmas II Dinas Kesehatan Kecamatan Denpasar Barat, terdapat 1413 kasus diare pada balita yang telah ditemukan dan dilayani 1078 kasus diare. Case Fatality Rate (CFR) diare wilayah kerja Puskesmas II Denpasar Barat adalah 0 (Puskesmas II Denbar, 2020). Berdasarkan hasil dari studi pendahuluan, pemegang program diare mengatakan kejadian diare pada balita di UPTD Puskesmas II Dinas Kesehatan Kecamatan Denpasar Barat masih sering terjadi dan ditemukan di setiap bulan.

Dalam rangka meningkatkan derajat kesehatan masyarakat khususnya pada golongan balita, diadakan Posyandu di Kota Denpasar. Posyandu dikelola dan diselenggarakan masyarakat. Posyandu memiliki lima program prioritas yaitu kesehatan ibu dan anak, keluarga berencana, imunisasi, gizi serta pencegahan dan penanggulangan diare. Di Kota Denpasar ratio posyandu dengan balita adalah 1 posyandu melayani 100 balita (Dinkes Kota Denpasar, 2020). Berdasarkan Dinkes Kota Denpasar (2020), penanggulangan diare difokuskan pada penanganan penderita untuk mencegah terjadinya kematian. Selain itu, dilakukan promosi kesehatan terkait hygiene sanitasi dan makanan untuk mencegah terjadinya penyebarluasan kasus (KLB). Upaya yang dilakukan oleh tenaga kesehatan baik oleh puskesmas maupun dinas kesehatan 
adalah meningkatkan penyuluhan kesehatan kepada masyarakat, kaporitisasi air minum dan peningkatan sanitasi lingkungan.

Penyebab utama kematian diare yaitu dehidrasi yang terjadi akibat kehilangan cairan dan elektrolit melalui feses. Sementara penyebab lainnya adalah disentri, gizi, dan infeksi. Balita yang mengalami diare akan memiliki risiko mengalami dehidrasi. Dehidrasi dapat terjadi tergantung pada persentase cairan tubuh yang hilang. Dehidrasi yang terjadi dapat dikategorikan menjadi diare tanpa dehidrasi, dehidrasi ringan/sedang, serta dehidrasi berat (Christy, 2014). Beberapa faktor penyebab terjadinya diare pada balita, seperti faktor infeksi yang disebabkan oleh sejumlah bakteri, virus, dan parasit, faktor malnutrisi, sumber air yang terkontaminasi tinja. Faktor infeksi dari bakteri dan virus seperti Rotavirus, Escherichia coli (e.coli) adalah yang paling umum dari kasus diare yang terjadi di negara-negara berpenghasilan rendah (WHO, 2017).

Dehidrasi yang dialami oleh balita diperlukan penanganan yang tepat mengingat dampak yang dapat disebabkan dehidrasi cukup fatal, seperti kehilangan cairan dan bahkan dapat menyebabkan kematian sehingga dibutuhkan pengobatan yang tepat. Pengobatan utama yang harus dilakukan terhadap diare adalah rehidrasi serta penggantian air serta elektrolit yang hilang. Upaya tersebut dikenal dengan Upaya Rehidrasi Oral (URO) (Christy, 2014). Rehidrasi cairan pada balita yang berusia 1 - 5 tahun dengan cara memberikan cairan infus ringer laktat, bila tidak tersedia cairan infus ringer laktat, dapat diganti dengan menggunakan $\mathrm{NaCl}$ $(0,9 \%)$. Rehidrasi cairan pada anak usia 1-5 tahun (balita) dengan memberikan cairan infus ringer laktat, bila tidak tersedia dapat menggunakan $\mathrm{NaCl} \quad 0,9 \%$. Menurut Direktorat Jenderal Pengendalian Penyakit dan Penyehatan Lingkungan (2011), rencana pengobatan diare dibagi menjadi 3 berdasarkan derajat keparahan dehidrasi yang dialami balita yaitu diare tanpa dehidrasi (terapi A), dehidrasi ringan/sedang (terapi B), dehidrasi berat (terapi C).

Beberapa penelitian menunjukan fakta terkait dengan kejadian diare, seperti pada penelitian yang dilakukan oleh Prajnyaswari dan Putri (2018), dengan sampel yang diteliti yaitu balita berjenis kelamin laki-laki (52\%) dan balita perempuan $(48 \%)$, riwayat kejadian diare cenderung lebih tinggi pada balita berjenis kelamin laki-laki $(87,2 \%)$ dibandingkan balita perempuan $(77,8 \%)$. Pada balita yang berusia $12-36$ bulan dengan jumlah $(60 \%)$ dan usia 37-60 bulan (40\%), kejadian diare cenderung lebih tinggi pada balita yang berusia $12-36$ bulan $(91,1 \%)$ dibandingkan dengan balita usia 37-60 bulan (70\%). Pada penelitian yang dilakukan oleh Febriansiswanti (2015), untuk pasien dengan pemberian infus ringer laktat dengan rentang usia 1-3 tahun sebanyak 48 $(64 \%)$, sedangkan pada pasien dengan rentang usia 4-5 tahun terdapat 27 pasien (36\%). Pada penelitian Selvia (2017), dari sebagian besar pasien yang datang dengan keluhan $\mathrm{BAB}$ encer disertai dengan keluahan demam, muntah, dan pasien yang melakukan pemeriksaan lab dengan hasil leukosit, sebagian besar pasien mendapat terapi antibiotik yakni 61,7\%.

Berdasarkan data-data di atas, penelitian ini bertujuan untuk mendeskripsikan Gambaran Kejadian Diare Pada Balita Di UPTD Puskesmas II Dinas Kesehatan Kecamatan Denpasar Barat Periode JuniNovember Tahun 2019, berdasarkan karakteristik sosiodemografi yaitu jenis kelamin, usia, dan tempat tinggal, serta derajat dehidrasi dan juga pengobatannya yaitu pemberian cairan ringer laktat dan pemberian antibiotik. 


\section{METODE PENELITIAN}

Penelitian ini merupakan penelitian kuantitatif, dengan rancangan penelitian deskriptif dan menggunakan desain penelitian cross sectional. Penelitian ini dilakukan pada bulan Desember 2020 Februari 2021 yang bertempat di UPTD Puskesmas II Dinas Kesehatan Kecamatan Denpasar Barat.

Sampel pada penelitian ini dipilih berdasarkan kriteria inklusi dan eksklusi yang ditetapkan. Teknik pengambilan sampel dilakukan dengan cara total sampling yaitu sebanyak 79 balita. Data yang dikumpulkan pada penelitian ini bersumber dari data sekunder. Pengumpulan data sekunder diawali dengan bersurat kepada Dinas Kesehatan Kota Denpasar, dilanjutkan kepada Dinas Penanaman Modal dan Pelayanan Satu Pintu Provinsi Bali, kemudian kepada Badan Kesbangpol Porvinsi Bali dan Badan Kesbangpol Kota Denpasar, dan diakhiri bersurat kepada UPTD Puskesmas II Dinas Kesehatan Kecamatan Denpasar Barat. Pengumpulan data sekunder dilakukan dengan cara menghubungi pemegang program diare yang bertempat di UPTD Puskesmas II Dinas Kesehatan Kecamatan Denpasar Barat. Data sekunder yang diperoleh berupa data elektronik/soft copy yang diberikan oleh pemegang program diare. Proses pengumpulan data sekunder bertahap dilakukan dari bulan Desember 2020 - Februari 2021.

Metode analisis data penelitian ini dilakukan dengan analisis univariat menggunakan aplikasi software statistika pengola data. Analisis univariat dilakukan terhadap setiap variabel penelitian untuk mendistribusikan secara umum data hasil penelitian. Gambaran umum dilakukan dengan menggunakan distribusi frekuensi masing-masing variabel. Variabel yang dianalisis dengan analisis univariat adalah variabel berupa jenis kelamin, usia, tempat tinggal, derajat dehidrasi, pemberian cairan ringer laktat, dan pemberian antibiotik.

\section{HASIL}

Tabel 1 menunjukan kejadian diare terbanyak dialami oleh balita berjenis kelamin laki-laki sebanyak 48 balita $(60,76 \%)$, mayoritas usia pada balita penderita diare yaitu 12 - 36 bulan sebanyak 43 balita (54,43\%), kasus diare pada balita terbanyak terjadi di Desa Padangsambian Kelod sebanyak 26 balita $(32,91 \%)$, mayoritas balita menderita diare tanpa dehidrasi sebanyak 60 balita $(75,95 \%)$, terdapat pemberian cairan ringer laktat kepada balita penderita diare sebanyak 21 balita $(26,58 \%)$, terdapat pemberian antibiotik kepada balita penderita diare sebanyak 10 balita $(12,66 \%)$. 
Tabel 1. Distribusi Kejadian Diare Berdasarkan Jenis Kelamin, Usia, Tempat Tinggal, Derajat Dehidrasi, Pemberian Cairan Ringer Laktat, dan Pemberian Antibiotik

\begin{tabular}{|c|c|c|}
\hline & Frekuensi & Persentase (\%) \\
\hline \multicolumn{3}{|l|}{ Jenis Kelamin } \\
\hline Laki-laki & 48 & $60,76 \%$ \\
\hline Perempuan & 31 & $39,42 \%$ \\
\hline \multicolumn{3}{|l|}{ Usia } \\
\hline $0-11$ bulan & 21 & $26,58 \%$ \\
\hline 12 - 36 bulan & 43 & $54,43 \%$ \\
\hline $37-60$ bulan & 15 & $18,99 \%$ \\
\hline \multicolumn{3}{|l|}{ Tempat Tinggal } \\
\hline Pemecutan Kelod & 20 & $25,32 \%$ \\
\hline Padangsambian Kelod & 26 & $32,91 \%$ \\
\hline Dauh Puri Kauh & 22 & $27,85 \%$ \\
\hline Kelurahan Dauh Purih Kauh & 6 & $7,59 \%$ \\
\hline Dauh Puri Kelod & 3 & $3,80 \%$ \\
\hline Dauh Pur Kangin & 2 & $2,53 \%$ \\
\hline \multicolumn{3}{|l|}{ Derajat Dehidrasi } \\
\hline Diare tanpa dehidrasi & 60 & $75,95 \%$ \\
\hline Dehidrasi ringan/sedang & 19 & $24,05 \%$ \\
\hline \multicolumn{3}{|c|}{ Pemberian Cairan Ringer Laktat } \\
\hline Ya & 21 & $26,58 \%$ \\
\hline Tidak & 58 & $73,42 \%$ \\
\hline \multicolumn{3}{|l|}{ Pemberian Antibiotik } \\
\hline Ya & 10 & $12,66 \%$ \\
\hline Tidak & 69 & $87,34 \%$ \\
\hline
\end{tabular}

\section{DISKUSI}

\section{Jenis Kelamin}

Hasil analisis data menunjukkan dari total 79 balita, proporsi kejadian diare lebih banyak ditemukan pada balita laki-laki sebanyak 48 balita (60,76\%). Penelitian yang dilakukan oleh Vernanda, Savira, dan Anggraini (2015), menunjukan bahwa kejadian diare pada balita tertinggi terjadi pada balita laki-laki sebesar 59,5\%. Pada penelitian lainnya yang dilakukan oleh Susanti, Novrikasari, dan Sunarsih (2016), menunjukan bahwa kejadian tertinggi diare pada balita terjadi pada balita berjenis kelamin laki-laki sebesar 50,7\%. Hal tersebut terjadi dikarenakan anak lakilaki cenderung lebih aktif dibandingkan anak perempuan, dengan status fisik yang lebih kuat memungkinkan gerak anak lakilaki lebih banyak dibandingkan perempuan sehingga lebih mudah terpapar agen penyebab diare
(Sinthamurniwaty, 2006). Berbeda dengan penelitian yang dilakukan oleh Yusuf (2011), menunjukan bahwa kejadian tertinggi diare pada balita perempuan lebih tinggi yaitu sebesar 51,9\%. Beberapa penelitian lainnya mencantumkan bahwa walau terdapat beberapa perbedaan angka diare pada balita laki-laki maupun perempuan, tidak ditemukan perbedaan yang signifikan (Vernanda et al, 2015).

\section{Usia}

Hasil analisis data menunjukkan dari total 79 balita, proporsi kejadian diare pada balita paling banyak terjadi pada kategori umur 12 - 36 bulan dengan jumlah sebanyak 43 kasus (54,43\%). Pada penelitian yang dilakukan oleh Soentpiet, Manoppo dan Wilar (2015), menunjukkan kejadian diare terbanyak terdapat pada balita dengan rentang usia 3 - 5 tahun yaitu sebanyak 45,8\%. Pada penelitian lainnya yang dilakukan oleh Setiawan dan Ani (2017), menunjukan bahwa balita yang 
mengalami diare terbanyak terjadi pada kelompok usia 17 - 26 bulan sebanyak $29,2 \%$. Pada penelitian lainnya juga yang dilakukan oleh Vernanda, Savira, dan Anggraini (2015), menujukan bahwa kejadian diare pada balita ditemukan paling banyak terjadi pada rentang usia 12 - 59 bulan sebanyak 93,6\%. Menurut Vernanda, Savira, dan Anggraini (2015), balita berumur 12 - 59 lebih rentan terkena diare dikarenakan sudah mendapatkan makanan tambahan lainnya selain ASI. Hal ini menyebabkan mudahnya balita pada usia tersebut memakan makanan yang telah terkontaminasi agen penyebab diare. Selain itu, balita usia 12 - 59 bulan lebih aktif dalam bergerak dan sudah mulai belajar berjalan, sehingga menjadi lebih aktif bermain di lingkungan sekitar rumah dan seringkali tanpa pengawasan orang tua, sehingga lebih mudah terpapar agen penyebab diare.

\section{Tempat Tinggal}

Hasil analisis data menunjukkan dari total 79 balita, kejadian diare pada balita paling banyak ditemukan dari Desa Padangsambian Kelod yaitu sebanyak 26 kasus (32,91\%). Penelitian yang dilakukan oleh Mariyani dan Hamami (2018), menunjukan bahwa terdapat hubungan yang signifikan antara sanitasi lingkungan tempat tinggal ibu dengan kejadian diare pada balita. Pada penelitian lain yang dilakukan oleh Prasetyo dan Siagian (2017), kecenderungan balita untuk menderita penyakit diare lebih tinggi terjadi pada balita yang tinggal di lingkungan kumuh. Ditinjau dari berbagai aspek yang ada seperti lokasi, sarana dan prasarana lingkungannya, lokasi seperti ini tidak layak untuk dijadikan tempat tinggal sehingga masyarakat yang tinggal di pemukiman kumuh sangat rentan untuk terserang penyakit berbasis lingkungan. Pada penelitian lain yang dilakukan oleh Margarethy, Suryaningtyas, dan Yahya
(2020), menunjukan bahwa tingginya jumlah penduduk berhubungan dengan kepadatan tempat tinggal. Kepadatan penduduk yang tinggi menyebabkan kondisi sanitasi lingkungan menjadi buruk, sehingga memiliki kemungkinan lebih besar terjadi penyakit diare. Berdasarkan Data Dinas Perumahan, Kawasan Permukiman Dan Pertanahan Kota Denpasar tidak terdapat daftar lokasi kumuh di desa Padangsambian Kelod. Tetapi, berdasarkan data demografi dari UPTD Puskesmas II Dinas Kesehatan Kecamatan Denpasar Barat di tahun 2019, jumlah penduduk di Desa Padangsambian Kelod merupakan yang terbanyak kedua dengan jumlah penduduk sebesar 28.467 jiwa. Hal ini dapat mempengaruhi berbagai sektor termasuk sektor kesehatan sehingga memerlukan perhatian yang lebih serius (Puskesmas II Denbar, 2019).

\section{Derajat Dehidrasi}

Hasil analisis data menunjukkan dari total 79 balita, mayoritas kejadian diare pada balita adalah diare tanpa dehidrasi yaitu 60 balita $(75,95 \%)$ penderita. Selain itu, terdapat 19 balita $(24,05 \%)$ penderita diare juga menderita diare dengan dehidrasi ringan/sedang. Pada penelitian yang dilakukan oleh Zubaidah, dan Maria (2020), menunjukan bahwa mayoritas balita mengalami diare tanpa dehidrasi yaitu sebanyak 23 balita (58\%), selain itu terdapat balita yang mengalami diare dengan dehidrasi ringan-sedang yaitu sebanyak 17 balita (42\%). Pada penelitian yang dilakukann oleh Wulandari (2010) dalam Ridaul Chasanah (2018), diare akut terbanyak yaitu diare akut dengan dehidrasi ringan sampai sedang sebanyak 59,52\%. Balita dan anak-anak lebih mudah mengalami dehidrasi dibanding usia dewasa. Resiko dehidrasi pada anak balita menjadi lebih besar karena komposisi cairan tubuh yang besar dan ketidakmampuan memenuhi kebutuhan 
sendiri secara bebas (Zubaidah \& Maria, 2020). Menurut Amalia et al (2015), penyebab dehidrasi adalah kehilangan cairan yang berlebihan atau kekurangan cairan yang masuk kedalam tubuh. Hal ini terjadi jika cairan yang disekresi lebih banyak dari kapasitas absorpsi atau adanya kegagalan absorpsi. Dehidrasi bisa terjadi akibat diare dan muntah. Selama diare akan terjadi peningkatan kehilangan cairan dan elektrolit melalui feses. Anak balita memiliki risiko yang lebih besar mengalami dehidrasi karena komposisi cairan tubuh yang besar dan ketidakmampuan untuk memenuhi kebutuhan sendiri secara bebas. Ketika kehilangan cairan terus berlangsung dan tidak diimbangi dengan penggantian yang cukup, maka akan berakhir menjadi dehidrasi. Dan jika keadaan ini berlangsung terus maka dapat terjadi dehidrasi berat dan bahkan kematian.

\section{Pemberian Cairan Ringer Laktat}

Hasil analisis data menunjukan dari total 79 balita, terdapat 21 balita (26,58\%) penderita diare yang mendapatkan cairan ringer laktat. WHO (World health organization) menganjurkan pemakaian ringer laktat dalam mengatasi dehidrasi berat dan dehidrasi ringan/sedang disaat memberikan cairan peroral tidak memungkinkan (Salwan et al, 2008). Berdasarkan Direktorat Jenderal Pengendalian Penyakit dan Penyehatan Lingkungan (2011), cairan ringer laktat digunakan pada rencana terapi $\mathrm{C}$ yaitu untuk terapi diare dengan dehidrasi berat di sarana kesehatan. Pemberian cairan infus ringer laktat pada penderita diare bertujuan untuk mengganti cairan tubuh yang hilang saat terjadi diare dengan dehidrasi ringan/sedang sampai dengan berat (Chasanah, 2018). Pada penelitian yang dilakukan oleh Ridaul Chasanah (2018), menemukan bahwa sebagaian besar balita yaitu sebanyak 55 balita $(91,7 \%)$ yang terkena diare diberikan cairan ringer laktat.

\section{Pemberian Antibiotik}

Hasil analisis data menunjukkan dari total 79 balita, terdapat 10 balita $(12,66 \%)$ penderita diare yang mendapatkan antibiotik. Menurut WHO pemberian antibiotik hanya diindikasikan pada pasien diare disertai dengan demam, darah pada feses, suspek kolera, dan infeksi berat lainnya. Pada penelitian yang dilakukan oleh Selvia (2016), dari sebagian besar pasien balita yang datang dengan keluhan $\mathrm{BAB}$ encer disertai dengan keluahan demam dan muntah yakni $42,5 \%$, dan pasien balita yang melakukan pemeriksaan lab dengan hasil leukosit yakni 5,8\%, sebagian besar pasien balita mendapat terapi antibiotik yakni sebesar $61,7 \%$. Pada penelitian lainya yang dilakukan oleh Agtini dan Puspandari (2017), menunjukan bahwa proporsi penggunaan antibiotik sebagai terapi diare pada balita di puskesmas sebesar 26,09\% dan di rumah sakit sebesar 29,17\%. Selain itu, penelitian Namru dan Badan litbangkes dalam Agtini dan Puspandari (2017), menyebutkan penggunaan antibiotik hanya sebesar $8,4 \%$ dari kejadian diare pada balita yang disebabkan oleh bakteri. Sehingga pemberian antibiotik pada balita penderita diare harus dilakukan dengan hati-hati dan mempertimbangkan agen penyebabnya. Kasus diare terbanyak biasanya akibat virus, yang tidak membutuhkan penanganan dengan menggunakan antibiotik, dan dapat sembuh alami tanpa pengobatan. Penggunaan antibiotik yang tidak logis dalam mengatasi infeksi akibat dari bakteri dan virus penyebab diare, tidak efektif untuk mengatasi infeksi serta dapat memperburuk penyakit, selain itu dapat memunculkan efek samping, meningkatkan biaya pengobatan dan menyebabkan terjadinya resistensi antibiotik. 


\section{SIMPULAN}

Gambaran penderita diare pada balita di UPTD Puskesmas II Dinas Kesehatan Kecamatan Denpasar Barat Periode JuniNovember Tahun 2019 berdasarkan jenis kelamin, lebih banyak dialami oleh balita berjenis kelamin laki-laki, dengan persentase balita yang berjenis kelamin laki-laki yaitu sebanyak 48 kasus $(60,76 \%)$.. Gambaran penderita diare pada balita di UPTD Puskesmas II Dinas Kesehatan Kecamatan Denpasar Barat Periode JuniNovember Tahun 2019 berdasarkan usia, paling banyak terjadi pada kategori usia 12 - 36 bulan dengan jumlah sebanyak 43 kasus (54,43\%). Gambaran penderita diare pada balita di UPTD Puskesmas II Dinas Kesehatan Kecamatan Denpasar Barat Periode Juni-November Tahun 2019 berdasarkan tempat tinggal, paling banyak yang tercatat dalam data puskesmas adalah dari Desa Padangsambian Kelod yaitu sebanyak 26 kasus (32,91\%). Gambaran penderita diare pada balita di UPTD Puskesmas II Dinas Kesehatan Kecamatan Denpasar Barat Periode JuniNovember Tahun 2019 berdasarkan derajat dehidrasi, mayoritas mengalami diare tanpa dehidrasi yaitu 60 balita (75,95\%). Selain itu, terdapat 19 balita $(24,05)$ penderita diare juga menderita diare dengan dehidrasi ringan/sedang. Gambaran penderita diare pada balita di UPTD Puskesmas II Dinas Kesehatan Kecamatan Denpasar Barat Periode JuniNovember Tahun 2019 berdasarkan pemberian cairan ringer laktat, terdapat 21 balita $(26,58 \%)$ penderita diare yang mendapatkan cairan ringer laktat di UPTD Puskesmas II Dinas Kesehatan Kecamatan Denpasar Barat Periode Juni-November Tahun 2019. 6. Gambaran penderita diare pada balita di UPTD Puskesmas II Dinas Kesehatan Kecamatan Denpasar Barat Periode Juni-November Tahun 2019 berdasarkan pemberian antibiotik, terdapat 10 balita $(12,66 \%)$ penderita diare yang mendapatkan antibiotik di UPTD Puskesmas II Dinas Kesehatan Kecamatan Denpasar Barat Periode Juni-November Tahun 2019.

\section{SARAN}

Sebagai upaya pencegahan penderita diare pada balita, terutama pada balita laki-laki, dan balita yang memiliki rentang usia sekitar 12 - 36 bulan yang memiliki jumlah penderita diare terbanyak, disarankan kepada puskesmas melalui posyandu lebih intensif melakukan program sosialisasi terkait tindakan pencegahan yang dapat dilakukan oleh orang tua dari balita, sehingga dapat mencegah terjadinya diare pada balita. Sebagai upaya penanganan penderita diare pada balita, terutama pada balita yang mengalami diare dengan dehidrasi, disarankan kepada puskesmas melalui posyandu melakukan sosialisasi terkait tindakan penanganan yang harus segera dilakukan oleh orang tua jika balita mengalami diare, khususnya pada orang tua yang memiliki balita yang mengalami diare dengan dehidrasi sebelum mendapatkan penanganan di rumah sakit oleh tenaga medis, agar tidak berisiko bertambah parah sehingga dapat meminimalisir terjadinya diare dan diare dengan dehidrasi.

\section{UCAPAN TERIMA KASIH}

Dalam penulisan artikel ini, penulis banyak mendapat motivasi, saran, masukan, dan bimbingan dari berbagai pihak. Untuk itu, pada kesempatan ini penulis berterimakasih kepada Dr. dr. Komang Januartha Putra Pinatih, M.Kes, sebagai Dekan Fakultas Kedokteran Universitas Udayana; dr. Putu Ayu Swandewi Astuti, S.Ked MPH, PhD, sebagai Koordinator Program Studi Kesehatan Masyarakat Universitas Udayana; Dr. drh. I Made Subrata, M.Erg, sebagai pembimbing yang banyak 
Arc. Com. Health • Desember 2021

p-ISSN 2302-139X e-ISSN 2527-3620

Vol. 8 No.3: 398 - 408

memberikan arahan dan masukan kepada penulis terkait proposal yang dikerjakan; Kedua orang tua yang tidak henti-hentinya memberikan doa terbaik kepada penulis; dan berbagai pihak yang terkait dalam penyelesaian artikel ini. Penulis tidak henti-hentinya mengucapkan terima kasih terhadap semua pihak yang terkait. 


\section{DAFTAR PUSTAKA}

Agtini, D. M. and Puspandari, N. (2017). Penggunaan antibiotika pada balita dengan diare akut di 5 provinsi di Indonesia tahun 2009-2012. Jurnal Biotek Medisiana Indonesia, 6(1), pp. 1-8.

Amalia, N. W., Mauliza, M. and Wahyuni, S. (2018). Hubungan Kadar Hemoglobin Dengan Lama Rawat Pasien Anak Diare Di Badan Layanan Umum Daerah Rumah Sakit Umum Cut Meutia Kabupaten Aceh Utara Tahun 2015. AVERROUS: Jurnal Kedokteran dan Kesehatan Malikussaleh, 3(2), pp. 18-28.

Chasanah, R. (2018). Studi Deskriptif Resusitasi Cairan Pada Anak Diare Dengan Dehidrasi Di Rumah Sakit Islam Kendal. Universitas Muhammadiyah Semarang.

Christy, M. Y. (2014). Faktor yang berhubungan dengan kejadian dehidrasi diare pada balita di wilayah kerja Puskesmas Kalijudan. Jurnal Berkala Epidemiologi, 2(3), pp. 297308.

Dinas Kesehatan Kota Denpasar (2020). Profil Dinas Kesehatan Kota Denpasar Tahun 2019. Denpasar: Dinas Kesehatan Kota Denpasar.

Dinas Kesehatan Provinsi Bali (2020). Profil Kesehatan Provinsi Bali 2019. Bali: Dinas Kesehatan Provinsi Bali.

Direktorat Jenderal Pengendalian Penyakit dan Penyehatan Lingkungan (2011). Panduan Sosialisasi Tatalaksana Diare Balita. Jakarta: Kementerian Kesehatan Republik Indonesia.

Febriansiswanti, N. M. D. (2016). Efektivitas Infus Ringer Laktat Dan Infus Ringer Laktat Dengan Zink Berdasarkan Lama Rawat Inap Pada Pengelolaan Diare Anak Usia 1-5 Tahun. CALYPTRA, 4(2), pp. 1-13.

Kementerian Kesehatan Republik Indonesia (2020). Profil Kesehatan
Indonesia 2019. Jakarta: Kementerian Kesehatan Republik Indonesia.

Mariyani and Hamami, H. A. S. (2018). Faktor-Faktor Yang Berhubungan Dengan Kejadian Diare Pada Balita. Jurnal Antara Keperawatan, 1(1), pp. 8-19.

Prajnyaswari, D. A. I. S. and Putri, W. C. W. S. (2018). Gambaran riwayat kejadian diare pada balita dan pelaksanaan PHBS dalam tatanan rumah tangga di Desa Gegelang Keca matan Manggis tahun 2013. Intisari Sains Medis, 9(1).

Prasetyo, R. and Siagian, T. H. (2018). Determinan penyakit berbasis lingkungan pada anak balita di Indonesia. Jurnal Kependudukan Indonesia, 12(2), pp. 93-104.

Salwan, H. et al. (2016). Gambaran kadar natrium dan kalium plasma berdasarkan status nutrisi sebelum dan sesudah rehidrasi pada kasus diare yang dirawat di departemen IKA RSCM. Sari Pediatri, 9(6), pp. 406411.

Selvia, A. A. (2017). Karakteristik Penderita Diare Pada Balita yang Di Rawat Inap Di RSUD Daya Kota Makassar Periode Januari-Desember 2016 (Skripsi). Makassar: Universitas Hasanuddin. Available at: http://digilib.unhas.ac.id/uploaded_fil es/temporary/DigitalCollection/NWN kZTgwZmNiYjE4NWFhNDhiZmM2 MzQzZjk1ZjA5MjcxOWQwNmQ4ZA $==$.pdf.

Setiawan, I. and Ani, L. S. (2017). Kejadian Diare Pada Balita Di Wilayah Kerja Puskesmas Tembuku Kabupaten Bangli Tahun 2016. E-Jurnal Med, 6(5), pp. 12-20.

Sinthamurniwaty, S. (2006). Faktor-Faktor Risiko Kejadian Diare Akut Pada Balita (Studi Kasus di Kabupaten Semarang). Semarang: Universitas Diponegoro. 
Soentpiet, M. G. O., Manoppo, J. I. C. and Wilar, R. (2015). Hubungan Faktor Sosiodemografi dan Lingkungan dengan Diare pada Anak Balita di Daerah Aliran Sungai Tondano. eCliniC, 3(3).

Susanti, W. E., Novrikasari, N. and Sunarsih, E. (2016). Determinan Kajadian Diare Pada Anak Balita di Indonesia (Analisis Lanjut Data SDKI 2012). Jurnal Ilmu Kesehatan Masyarakat, 7(1), p. 58006.

Unicef (2020). Diarrhoea remains a leading killer of young children, despite the availability of a simple treatment solution. Available at: https://data.unicef.org/topic/childhealth/diarrhoeal-disease/ (Accessed: 26 November 2020).

Vernanda, S. G., Savira, M. and Anggraini, D. (2014). Karakteristik pada Balita Diare dengan Infeksi Enteropathogenic Escherichia Coli (Epec) di Puskesmas Rawat Inap Kota Pekanbaru. Riau: Universitas Riau.

WHO (2017). Diarrhoeal disease. Available at: https://www.who.int/newsroom/fact-sheets/detail/diarrhoealdisease (Accessed: 23 February 2019).

Yusuf, S. (2016). Profil diare di ruang rawat inap anak. Sari pediatri, 13(4), pp. 265270.

Zubaidah, Z. and Maria, I. (2020). Hubungan Penatalaksanaan Pemberian Cairan Dirumah Dengan Tingkat Dehidrasi Pada Balita Yang Mengalami Diare', Jurnal Keperawatan Suaka Insan (JKSI). 5(1), pp. 121-126. 